\title{
Persepsi dan preferensi kenyamanan pejalan kaki tunanetra terhadap jalur pedestrian di Jalan Panglima Besar Sudirman, Kota Denpasar
}

\author{
Titin Maghfirotus Sa'adahํㅗ Naniek Kohdrata1*, Cokorda Gede Alit Semarajaya ${ }^{1}$ \\ 1. Program Studi Arsitektur Pertamanan, Fakultas Pertanian, Universitas Udayana, Indonesia 80362 \\ *E-mail: naniek_kohdrata@unud.ac.id
}

\begin{abstract}
Blind pedestrian perception and preference of comfort at pedestrian walkway at Panglima Besar Sudirman Street, Denpasar City. The main problem for the blind is limited public facilities in Indonesia. Denpasar is the capital province of Bali, so the need of physical infrastructure is very important. The aim of this research was to identify and evaluate the existing condition of the pedestrian path that is related to the comfort aspect, and to know the perception and preference of the blind pedestrian user to the comfort of the pedestrian path at Jalan P. B Sudirman Denpasar, and to recommend the accessibility model as supporting the needs and rights for those blind people. The research method were survey method with observation technique, questionnaires, and literature study. The inconsistency of pedestrian size and elevation between $15-35 \mathrm{~cm}$ of one of the causes of pedestrian walkway was considered unfit for use by the disadvantage people, thus the pedestrian lane space scenario at Jalan P. B Sudirman Denpasar is to make the pedestrian path as a mobilization path that is easily accessible to everyone and optimally in its utilization. The results of this study are expected to be a consideration for the parties concerned in the related development.
\end{abstract}

Keywords: blind perception and preference, blind pedestrian, pedestrian walk

\section{Pendahuluan}

Persoalan utama yang dihadapi oleh para penyandang tunanetra yaitu akses pendidikan serta fasilitas publik di Indonesia yang sangat terbatas. Salah satu kesulitan yang dialami seorang tunanetra adalah kemampuan bergerak dan berpindah tempat atau sering disebut dengan mobilitas. Seluruh aspek kehidupan dan kebutuhan seorang tunanetra akan dipengaruhi oleh ketidakmampuan dan keterbatasan tunanetra dalam bermobilitas (Indrawati, 2016).

Denpasar merupakan Ibu Kota Provinsi Bali sebagai pusat pemerintahan, sehingga kebutuhan infrastruktur fisik sangat penting dalam menunjang kemudahan aksesibilitas kegiatan dan perkembangan perkotaan. Jalur pedestrian merupakan salah satu prasarana infrastruktur fisik berupa jalan yang diperuntukkan bagi aktivitas pejalan kaki, sehingga jalur pedestrian sangat dibutuhkan keberadaannya bagi penyandang tunanetra sebagai jalur mobilisasi dalam memenuhi kebutuhan hidupnya.

Penelitian ini bertujuan untuk megidentifikasi dan mengevaluasi kondisi awal jalur pedestrian untuk mengetahui kelayakan kondisi fisik pedestrian sebagai jalur mobilisasi tunanetra, mengetahui persepsi dan preferensi kenyamanan pejalan kaki tunanetra di jalur pedestrian Jalan P. B Sudirman Denpasar, dan memberikan rekomendasi model aksesibilitas penyandang tunanetra.

\section{Metodologi Penelitian}

\subsection{Waktu dan Lokasi Penelitian}

Penelitian berlokasi di sepanjang jalur pedestrian Jalan P. B Sudirman Denpasar Kelurahan Dangin Puri Kecamatan Denpasar Timur Kota Denpasar Bali (Gambar 1). Penelitian dilaksanakan pada bulan Januari dan berakhir di bulan Agustus 2017. 


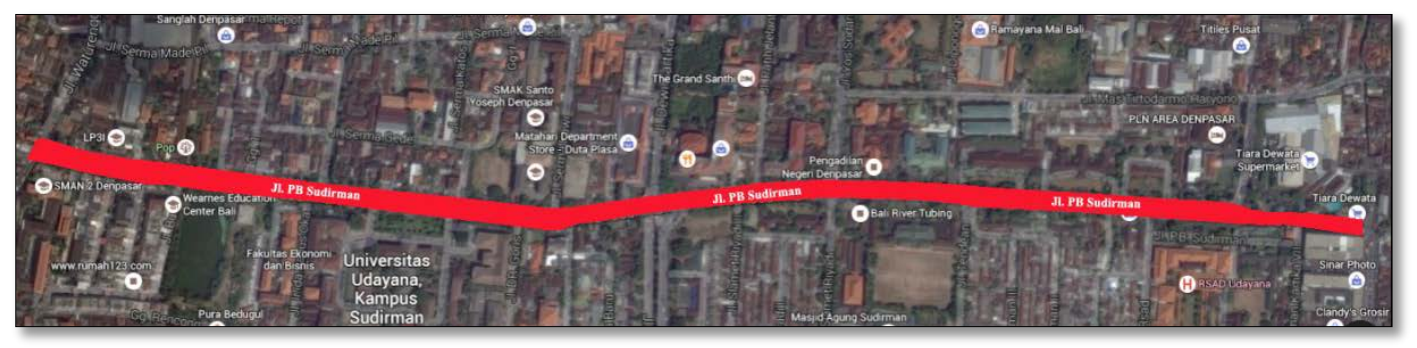

Gambar 1. Lokasi Penelitian

\subsection{Bahan dan Alat}

Bahan yang digunakan dalam penelitian yaitu lembar kuesioner, alat yang digunakan yaitu kamera digital, alat ukur, aplikasi GPS Essentials, software Microsoft Word, Microsoft Excel, Google Earth, Auto CAD, SketchUp, dan Photoshop.

\subsection{Metode Penelitian}

Metode penelitian yang digunakan yaitu metode survei. Pengumpulan data dilakukan dengan observasi langsung di lokasi penelitian, penyebaran kuesioner dan studi literatur. Metode analisis yang digunakan adalah metode deskriptif.

\subsection{Tahapan Penelitian}

Penelitian dimulai dari menentukan responden berdasarkan teknik pengambilan sampel dengan metode purposive sampling dengan jumlah 30 orang. Responden menilai keamanan serta kenyamanan jalur pedestrian di Jl. P B Sudirman Denpasar, kemudian dilanjutkan dengan inventarisasi, analisis, sintesis, dan berakhir pada tahap rekomendasi.

\subsection{Batasan Penelitian}

Responden pada penelitian ini dibatasi hanya kepada penyandang tunanetra (low vision dan total blind) yang pernah, sedang, atau rutin bermobilisasi pada jalur pedestrian Jalan P. B Sudirman Denpasar. Penelitian mengenai ruang hanya dibatasi pada kajian mobilitas penyandang tunanetra pada pedestrian di Jalan P. B Sudirman Denpasar. Lingkup pembahasan dalam penelitian ini hanya membahas aspek fisik.

\section{Hasil dan Pembahasan}

\subsection{Gambaran Umum Lokasi Penelitian}

Kota Denpasar berada pada ketinggian antara 0-75 m dpl, jenis tanah latosol cokelat kekuningan dan tanah aluvial (Pemerintah Daerah Kota Denpasar 2015). Suhu udara rata-rata Kota Denpasar pada Tahun 2015 adalah $27,6{ }^{\circ} \mathrm{C}$ dan kelembaban udara rata-rata 73\% (Badan Pusat Statistik Kota Denpasar 2016). Pengguna jalur pedestrian ini sangat beragam dari PNS, pegawai swasta, karyawan, TNI, siswa, mahasiswa, dan masyarakat umum. Pemanfaatan jalur pedestrian yaitu sebagai jalur pejalan kaki, sebagai ruang menunggu angkutan umum, bersosialisasi, dan sebagai lokasi untuk jogging saat pagi hari. Puncak keramaian kendaraan dan pejalan kaki di Jalan P. B Sudirman Denpasar terjadi pada jam 07.00 - 09.00 WITA saat pagi hari, 11.00 - 13.00 WITA saat siang hari, dan 17.00 - 18.00 WITA saat sore hari (Dishub Kota Denpasar, 2015).

\subsection{Aksesibilitas dan Sirkulasi}

Jalan P. B Sudirman Denpasar termasuk dalam klasifikasi jalan kolektor menurut jenisnya (Dinas Pekerjaan Umum Kota Denpasar 2015). Menurut UU No 38 Tahun 2004, Jalan Kolektor merupakan jalan umum yang berfungsi melayani angkutan pengumpul atau pembagi dengan ciri perjalanan jarak sedang, kecepatan rata-rata sedang, dan jumlah jalan masuk dibatasi (jalan dengan kapasitas tonase yang dibatasi).

\subsection{Kondisi Fisik Jalur Pedestrian}

Data skunder mengenai Kondisi jalur pedestrian di Jalan P. B Sudirman Denpasar pada akhir Tahun 2016 dalam keadaan baik sepanjang 1,274 km pada setiap sisinya dan dalam kondisi rata dengan aspal atau rusak sepanjang 0,3 km pada setiap sisinya (Dinas Pekerjaan Umum Kota Denpasar 2016). Data lain yang diperoleh saat survei diantaranya yaitu: 
1. Struktur badan jalan

Rusaknya jalur pedestrian akan berdampak pada keberlangsungan pejalan kaki tunanetra, permukaan yang tidak rata akan berpotensi terjadinya kecelakaan seperti tersandung, terpeleset, dan terjatuh.

2. Kontinuitas jalur pedestrian

Putusnya jalur pedestrian, kendaraan yang terparkir pada jalur pedestrian, serta keberadaan barang dagangan yang di letakkan pada jalur pedestrian telah menganggu dan menghambat pejalan kaki, terutama tunanetra. Bermobilisasi dengan menggunakan bantuan tongkat tidak menjamin tunanetra mampu memprediksi dan menghindari bahaya di sekitarnya.

3. Struktur pendukung jalur pedestrian

Tidak tersedianya area pemberhentian sementara pada median jalan dengan arus lalu lintas dua jalur, akan sangat menganggu keamanan serta kenyamanan bagi para pejalan kaki tunanetra saat menyeberang.

\subsection{Dimensi Jalur Pedestrian}

Panjang jalur pedestrian di Jl. P. B Sudirman Denpasar di akhir Tahun 2016 yaitu 1,574 km dan lebar $1,20 \mathrm{~m}$ pada masing-masing sisinya (Dinas Pekerjaan Umum Kota Denpasar 2017). Berikut merupakan kondisi dimensi pedestrian saat penelitian, yaitu:

1. Inkonsistensi ukuran jalur pedestrian

Inkonsistensi ukuran pedestrian yaitu terdapat jalur pedestrian dengan lebar antara $50-180 \mathrm{~cm}$. hal ini berdampak pada pejalan kaki tunanetra merasa kurang aman dan nyaman pada saat bermobilisasi.

2. Inkonsistensi elevasi jalur pedestrian

Perbedaan ketinggian yang secara tiba-tiba tanpa disertai ubin peringatan sebelumnya atau ramp sebagai penghubung sambungan pedestrian, berpotensi mencelakai pejalan kaki tunanetra.

\subsection{Material Jalur Pedestrian}

Unit material yang digunakan pada jalur pedestrian di sepanjang Jalan P. B Sudirman Denpasar yaitu paving berwarna merah dengan karakter kuat, tahan cuaca, dan bertekstur halus. Tidak semua jalur pedestrian dilengkapi dengan guiding block (jalur pemandu), namun terdapat beberapa jalur pedestrian yang telah dilengkapi dengan guiding blocks yang terdiri dari ubin pengarah bertekstur garis-garis dan ubin peringatan bertekstur bulat berwarna kuning. Beberapa permasalahan yang ditemukan saat proses analisis yaitu:

1. Kerusakan struktur

Kerusakan struktur jalur pedestrian diantaranya yaitu permukaan pedestrian yang tidak utuh dan tidak stabil, dan terdapat lubang pada jalur pedestrian.

2. Inkonsistensi penggunaan material

Kondisi beberap jalur pedestrian saat ini yaitu tidak tersedianya ubin tekstur pemandu.

\subsection{Street Furniture}

Street furniture yang ada di sepanjang Jalan P. B Sudirman Denpasara dinilai kurang lengkap. Street furniture yang tersedia yaitu tiga unit halte, dua unit signage (papan informasi) mengenai larangan membuang sampah sembarangan, marka jalan, serta rambu lalu lintas, sedangkan street furniture yang tidak tersedia di sepanjang jalur pedestrian adalah lampu penerangan, tempat duduk, tempat sampah, papan informasi, dan pagar pengaman pada lokasi yang berbahaya.

\subsection{Zebra Cross}

Terdapat beberapa area penyeberangan yang kurang aksesibel dikarenakan tidak tersedianya zebra cross pada persimpangan jalan, terdapat marka pengarah lalu lintas dan material lain yang menghalangi pejalan kaki, serta kontinuitas ubin pemandu menuju zebra cross kurang aksesibel bagi pejalan kaki tunanetra.

\subsection{Lampu Lalu Lintas}

Penambahan tanda suara (sound signal) sebagai pemberi isyarat kepada pejalan kaki saat menyeberang jalan merupakan salah satu upaya membantu para penyandang tunanetra. Tidak tersedianya lampu lalu lintas (Gambar 2) mengakibatkan pejalan kaki merasa kurang aman dan nyaman saat akan menyeberang jalan. 


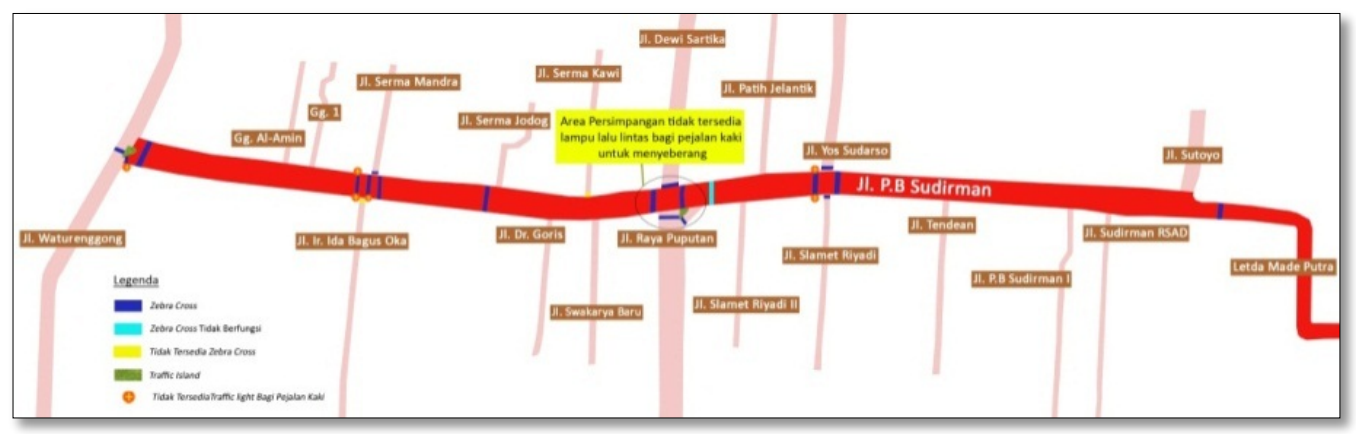

Gambar 2. Lokasi Tidak Tersedia Lampu Lalu Lintas Bagi Pejalan Kaki

\subsection{Tanaman Tepi Jalan}

Tanaman tepi jalan dapat menjadi penghalang dan berpotensi mencelakai pejalan kaki jika tidak dirawat secara intensif. Hasil survei terdapat akar pohon Angsana merusak konstruksi pedestrian, serta batang pohon dan ranting menghalangi pejalan kaki.

\subsection{Karakteristik Responden}

Karakteristik responden dikelompokkan berdasarkan jenis kelamin, usia, tingkat pendidikan, jenis mobilisasi, pasangan dalam bermobilisasi, frekuensi mobilisasi, waktu mobilisasi, serta bagian pedestrian yang diakses. Informasi tersebut untuk mengetahui kebutuhan dan kelayakan jalur pedestrian terhadap pengguna tunanetra.

\subsection{Persepsi Responden}

Parameter persepsi pejalan kaki tunanetra pada jalur pedestrian Jalan P. B Sudirman Denpasar yang digunakan adalah kondisi mengenai keamanan dan kenyamanan jalur pedestrian. Indikator mengenai kondisi keamanan dan kenyamanan dipertimbangkan berdasarkan hasil inventarisasi mengenai kondisi tapak yang dilakukan sebelum penyebaran kuesioner. Parameter keamanan terpisah dari parameter kenyamanan dikarenakan keamanan merupakan hal yang berbeda dengan kenyamanan, sehingga dalam persepsi dari responden perlu dibedakan untuk menghasilkan informasi yang lebih lengkap. Berikut merupakan hasil persentase jumlah responden dalam pemberian skor pada kondisi keamanan dan kenyamanan:

Tabel 1. Responden dalam Pemberian Skor pada Persepsi Kondisi Keamanan

\begin{tabular}{clccccc}
\hline NO & \multicolumn{1}{c}{ Kriteria Penilaian } & STA & TA & CA & A & SA \\
\hline 1 & Aksesibilitas dan sirkulasi & $6,6 \%$ & $16,7 \%$ & $60 \%$ & $16,7 \%$ & - \\
2 & Bahan atau material jalur pedestrian & - & $13,3 \%$ & $76,7 \%$ & $10 \%$ & - \\
3 & Keutuhan jalur pedestrian & $6,6 \%$ & $53,4 \%$ & $40 \%$ & - & - \\
4 & Keamanan dari tindak kriminal & - & - & - & $43,4 \%$ & $56,6 \%$ \\
5 & Lokasi zebra cross (tempat & - & $46,7 \%$ & $40 \%$ & $13,3 \%$ & - \\
& penyeberangan) & & & & & \\
6 & Lampu lalu lintas & - & - & $50 \%$ & $46,7 \%$ & $3,3 \%$ \\
7 & Tanaman tepi jalan & $26,7 \%$ & $53,3 \%$ & $20 \%$ & - & - \\
8 & Suara atau kebisingan & - & - & $36,7 \%$ & $63,3 \%$ & - \\
$\begin{array}{l}\text { Persentase Akhir Persepsi Kondisi } \\
\text { Keamanan }\end{array}$ & $\mathbf{5 \%}$ & $\mathbf{2 2 , 9 \%}$ & $\mathbf{4 0 , 4 \%}$ & $\mathbf{2 4 , 2 \%}$ & $\mathbf{7 , 5 \%}$ \\
\hline
\end{tabular}

Keterangan: STA = Sangat Tidak Aman, TA = Tidak Aman, CA = Cukup Aman, A = Aman, SA = Sangat Aman.

Tabel 2. Responden dalam Pemberian Skor Persepsi Kondisi Kenyamanan

\begin{tabular}{clccccc}
\hline NO & \multicolumn{1}{c}{ Kriteria Penilaian } & STN & TN & CN & N & SN \\
\hline 1 & Aksesibilitas dan sirkulasi & $3,3 \%$ & $20 \%$ & $73,4 \%$ & $3,3 \%$ & - \\
2 & Dimensi jalur pedestrian & $3,3 \%$ & $30 \%$ & $63,4 \%$ & $3,3 \%$ & - \\
3 & Bahan atau material jalur pedestrian & - & $20 \%$ & $73,3 \%$ & $6,7 \%$ & - \\
4 & Street furniture & - & $20 \%$ & $76,7 \%$ & $3,3 \%$ & - \\
5 & Lokasi zebra cross (tempat & $3,3 \%$ & $36,7 \%$ & $50 \%$ & $10 \%$ & - \\
& penyeberangan) & & & & & \\
\hline
\end{tabular}


Lanjutan Tabel 2

\begin{tabular}{clccccc}
\hline NO & \multicolumn{1}{c}{ Kriteria Penilaian } & STN & TN & CN & N & SN \\
\hline 6 & Lampu lalu lintas & $3,3 \%$ & $10 \%$ & $43,4 \%$ & $40 \%$ & $3,3 \%$ \\
7 & Tanaman tepi jalan & $33,3 \%$ & $46,7 \%$ & $20 \%$ & - & - \\
8 & Kebersihan & - & $13,3 \%$ & $60 \%$ & $26,7 \%$ & - \\
9 & Suara atau kebisingan & - & - & $40 \%$ & $60 \%$ & - \\
10 & Aroma atau bau-bauan & $3,3 \%$ & $30 \%$ & $53,4 \%$ & $13,4 \%$ & - \\
11 & Suhu & $3,3 \%$ & $6,7 \%$ & $50 \%$ & $40 \%$ & - \\
\hline $\begin{array}{l}\text { Persentase Akhir Persepsi Kondisi } \\
\text { Kenyamanan }\end{array}$ & $\mathbf{4 , 8 \%}$ & $\mathbf{2 1 , 2} \%$ & $\mathbf{5 4 , 9 \%}$ & $\mathbf{1 8 , 8 \%}$ & $\mathbf{0 , 3} \%$ \\
\hline
\end{tabular}

Keterangan: STN = Sangat Tidak Nyaman, TN = Tidak Nyaman, $\mathrm{CN}=$ Cukup Nyaman, $\mathrm{N}=$ Nyaman, $\mathrm{SN}=$ Sangat Nyaman.

Berikut merupakan hasil analisis gabungan mengenai persepsi kondisi keamanan dan kenyamanan pejalan kaki tunanetra terhadap jalur pedestrian di Jalan P. B Sudirman Denpasar:

1. Aksesibilitas dan sirkulasi

Persentase tertinggi dari persepsi keamanan mengenai aksesibilitas dan sirkulasi di jalur pedestrian dinilai cukup aman (CA) oleh responden dengan nilai 60\%, sedangkan persentase tertinggi dari penilaian kondisi kenyamanan yaitu $73,4 \%$ responden menilai cukup nyaman (CN). Penilaian tersebut dikarenakan sirkulasi pejalan kaki sepanjang jalur pedestrian tidak begitu padat, jalur pedestrian cukup mudah diakses karena telah dilengkapi dengan lampu lalu lintas dan zebra cross, akan tetapi sering kali pejalan kaki tunanetra tidak sengaja menabrak kendaraan yang terparkir.

Terdapat perbedaan mengenai persepsi positif responden dengan hasil analisis yang cenderung menilai kondisi fisik jalur pedestrian tidak nyaman. Alasannya, mayoritas responden menilai kenyamanan berdasarkan pengalaman mobilisasi yang telah menjadi kebiasaan pada bagian jalur pedestrian yang sering mereka akses, sehingga dengan hanya tersedia jalur pedestrian sebagai tempat bermobilisasi walaupun terdapat beberapa hambatan, menurut responden sudah cukup nyaman ketika mengaksesnya. Responden tidak menilai secara keseluruhan jalur pedestrian.

2. Bahan atau material jalur pedestrian

Persentase tertinggi dari persepsi keamanan mengenai material dinilai cukup aman (CA) oleh responden dengan nilai $76,7 \%$, sedangkan persentase tertinggi dari penilaian kondisi kenyamanan yaitu $73,3 \%$ responden menilai cukup nyaman (CN). Penilaian tersebut dikarenakan tekstur paving yang digunakan cukup aman dan nyaman karena tidak ada penggunaan banyak pola yang berpotensi terjadinya disorientasi dan kondisi material pedestrian dinilai cukup nyaman saat dilalui walaupun terasa sedikit licin ketika terkena air hujan. Berbeda dengan hasil analisis yang diperoleh mengenai material pedestrian saat ini dinilai tidak nyaman untuk diakses bagi pejalan kaki tunanetra, dikarenakan beberapa paving yang hilang dan digenangi air, terdapat lubang dibeberapa jalur pedestrian, dan tidak tersedianya jalur pemandu pada beberapa bagian pedestrian.

3. Dimensi jalur pedestrian

Persentase tertinggi dari persepsi kenyamanan mengenai dimensi pedestrian dinilai cukup nyaman (CN) oleh responden dengan nilai 63,4\%, selanjutnya terdapat 33,3\% responden menilai kondisi dimensi pedestrian saat ini tidak nyaman (TN). Ketinggian yang tidak konsisten membuat pejalan kaki tunanetra tidak nyaman saat bermobilisasi, akibatnya mereka lebih memilih berjalan di bagian tepi lajur sepeda motor, karena menurut mereka hal tersebut lebih aman dari lubang dan hambatan lainnya. Berbeda dengan pejalan kaki tunanetra yang terbiasa mengakses jalur pedestrian, mereka sudah hafal medan jalan yang akan dilaluinya.

4. Keutuhan jalur pedestrian

Persentase tertinggi dari persepsi keamanan mengenai keutuhan jalur pedestrian dinilai tidak aman (TA) oleh responden dengan nilai 60\%. Penilaian tersebut dikarenakan terdapat beberapa area jalur pedestrian yang rusak, terdapat lubang di beberapa jalur pedestrian yang membahayakan pejalan kaki, terdapat jalur pedestrian yang terputus, serta kurangnya ketersediaan jalur pemandu bagi pejalan kaki tunanetra. Keutuhan jalur pedestrian menjadi poin terpenting dari keselamatan pejalan kaki, karena hal tersebut menyangkut keselamatan pengguna pedestrian. 


\section{Keamanan dari tindakan kriminal}

Persentase tertinggi persepsi keamanan dari tindakan kriminal dinilai sangat aman (SA) oleh responden dengan nilai $56,6 \%$. Penilaian tersebut dikarenakan belum pernah ditemukan atau dialami kejadian tindakan kriminal untuk menganggu atau mencelakai pejalan kaki terutama penyandang tunanetra. Tindakan kriminal merupakan kasus yang sering kali terjadi di wilayah perkotaan, sehingga keamanan dari tindakan kriminal dalam penelitian ini perlu untuk dipertanyakan kepada responden sebagai penunjang kenyamanan pejalan kaki.

6. Street furniture

Persentase tertinggi dari persepsi kenyamanan mengenai keberadaan street furniture di jalur pedestrian dinilai cukup nyaman (CN) oleh responden dengan nilai $76,7 \%$. Penilaian tersebut dikarenakan street furniture saat ini cukup membentu bagi pejalan kaki. Hasil analisis mengenai street furniture yaitu tidak tersedianya lampu penerangan di sepanjang jalur pedestrian, tidak tersedianya tempat duduk untuk istirahat sementara, tidak tersedianya tempat sampah, papan informasi (signage) yang kurang lengkap, serta tidak tersedianya pagar pengaman pada lokasi yang berbahaya menjadikan kondisi street furniture saat ini dinilai tidak nyaman.

7. Lokasi zebra cross (tempat penyeberangan)

Persentase tertinggi mengenai tempat penyeberangan di jalur pedestrian dinilai tidak aman (TA) oleh responden dengan nilai $46,7 \%$, penilaian tersebut dikarenakan terdapat pengendara yang tidak taat rambu lalu lintas dengan tetap melaju pada saat lampu lalu lintas mengisyaratkan untuk berhenti, serta area penyeberangan dinilai kurang aman karena tidak tersedianya ruang tunggu sementara bagi penyeberang jalan.

Persentase tertinggi dari penilaian persepsi kondisi kenyamanan yaitu $50 \%$ responden menilai cukup nyaman $(\mathrm{CN})$ terhadap tempat penyeberangan. Penilaian tersebut dikarenakan keberadaan tempat penyeberangan cukup membantu mobilitas responden walaupun terdapat kendala saat mereka menyeberang, sedangkan hasil analisis menunjukkan kondisi zebra cross saat ini tidak nyaman karena pejalan kaki merasa terhambat saat bermobilisasi akibat terhalang material lain, serta area penyeberangan yang kurang aman.

8. Lampu lalu lintas

Persentase tertinggi mengenai lampu lalu lintas di jalur pedestrian dinilai cukup aman (CA) oleh responden dengan nilai $50 \%$, dan $43,3 \%$ responden menilai cukup nyaman (CN). Penilaian tersebut dikarenakan keberadaan lampu lalu lintas cukup membantu pejalan kaki tunanetra saat menyeberang jalan terutama dengan adanya sound signal, namun terdapat beberapa lampu lalu lintas dengan jeda yang sangat singkat, sehingga cukup menyulitkan penyeberang jalan dan pejalan kaki akan tergesa-gesa saat menyeberang untuk menghindari pengendara yang sedang melaju.

9. Tanaman tepi jalan

Persentase tertinggi mengenai tanaman tepi jalan di jalur pedestrian dinilai tidak aman (TA) oleh responden dengan nilai $80 \%$, dan $80 \%$ responden menilai tidak nyaman (TN). Penilaian tersebut dikarenakan terdapat akar pohon yang tumbuh dan merusak konstruksi pedestrian sering kali menyebabkan pejalan kaki tersandung, batang dan ranting pohon tumbuh menjorok ke badan pedestrian dan menghalangi pejalan kaki. Kondisi demikian menyebabkan persepsi yang negatif akibat tanaman tepi jalan yang tidak dirawat secara intensif.

10. Suara atau kebisingan

Persentase tertinggi mengenai kebisingan di jalur pedestrian dinilai aman (A) oleh responden dengan nilai $63,3 \%$, dan $60 \%$ responden menilai nyaman (N). Penilaian tersebut dikarenakan suara kendaraan yang berlalu-lalang dinilai tidak mengganggu pejalan kaki tunanetra, dan kebisingan yang ditimbulkan masih bisa ditoleransi oleh indra pendengaran responden. Suara yang ditimbulkan dari kendaraan bermotor dapat digunakan sebagai isyarat pejalan kaki tunanetra untuk menyeberang jalan, sehingga mereka merasa aman terhadap suara yang ditimbulkan.

11. Kebersihan

Persentase tertinggi mengenai kebersihan dinilai cukup nyaman $(\mathrm{CN})$ oleh responden dengan nilai $60 \%$. Penilaian tersebut dikarenakan responden belum pernah menemukan keberadaan sampah atau ranting pohon yang berserakan di jalur pedestrian dan menghambat mobilisasinya. 


\section{Aroma atau bau-bauan}

Persentase tertinggi mengenai aroma atau bau-bauan dinilai cukup nyaman (CN) oleh responden dengan nilai $53,4 \%$. Penilaian tersebut dikarenakan keberadaan aroma yang kurang sedap tidak sering dijumpai. Aroma yang kurang sedap sampai tidak sedap biasa dijumpai pada area-area tertentu, seperti pada area Tempat Pembuangan Sementara pada pedestrian bagian I.

13. Suhu

Persentase tertinggi mengenai kenyamanan suhu ynag ada di jalur pedestrian dinilai cukup nyaman (CN) oleh responden dengan nilai 50\%. Penilaian tersebut dikarenakan responden menilai kondisi kenyaman suhu berdasarkan waktu ketika mereka bermobilisasi, seperti ketika pagi hari, sore hari, dan malam hari. Hasil analisis diperoleh mengenai kondisi kenyamanan suhu di sepanjang jalur pedestrian berada pada tingkat tidak nyaman berada pada waktu siang hari.

Berdasarkan hasil analisis yang telah diuraikan menghasilkan data mengenai keamanan dapat mempengaruhi kenyamanan, namun kenyamanan tidak hanya di nilai berdasarkan kondisi keamanan saja, melainkan bisa dinilai dari segi suara, aroma, dan suhu. Data lain yang diperoleh yaitu pengalaman dan kebiasaan dari mayoritas responden telah menghasilkan penilaian kondisi keamanan pada kategori cukup aman dengan persentase $40,4 \%$, dan cukup nyaman dengan nilai $54,9 \%$. Penilaian tersebut diberikan tanpa respon pemahaman dan pengetahuan tentang pedoman yang berlaku dan tanpa mempertimbangkan pejalan kaki yang tidak aktif menggunakan jalur pedestrian, sehingga penilaian tersebut hanya mewakili studi kasus dalam penelitian ini.

\subsection{Preferensi Responden}

Indikator mengenai preferensi kenyamanan dipertimbangkan berdasarkan kebutuhan akan keberadaan fasilitas pendukung di jalur pedestrian. Berikut merupakan hasil dari preferansi responden mengenai sarana dan prasarana jalur pedestrian (Tabel 3).

Tabel 3. Responden dalam Pemberian Skor pada Preferensi Kenyamanan

\begin{tabular}{clccccc}
\hline N0 & \multicolumn{1}{c}{ Kriteria Penilaian } & STP & TP & CP & P & SP \\
\hline 1 & Ketersediaan street furniture & - & $30 \%$ & $43.4 \%$ & $20 \%$ & $6.6 \%$ \\
2 & Ketersediaan area penyeberangan (zebra & - & - & - & $26.7 \%$ & $73.3 \%$ \\
& $\begin{array}{l}\text { cross dan lampu lalu lintas) } \\
3\end{array}$ & & & & & \\
4 & Ketersediaan tanaman tepi jalan & $13.3 \%$ & $63.3 \%$ & $16.7 \%$ & $6.7 \%$ & - \\
& $\begin{array}{l}\text { Papan informasi (peta timbul dan } \\
\text { teks/touch signal) }\end{array}$ & - & $30 \%$ & $53.3 \%$ & $6.7 \%$ & $10 \%$ \\
5 & Alarm peringatan (sound signal) & - & - & $20 \%$ & $26.7 \%$ & $53.3 \%$ \\
\hline
\end{tabular}

Keterangan: STP $=$ Sangat Tidak Perlu, $\mathrm{TP}=$ Tidak Perlu, $\mathrm{CP}=$ Cukup Perlu, $\mathrm{P}=$ Perlu, $\mathrm{SP}=$ Sangat Perlu, $\mathrm{P}=$ Perlu, $\mathrm{SP}=$ Sangat Perlu.

Hasil penilaian pada Tabel 3 menunjukkan bahwa Preferensi atau prioritas yang lebih dibutuhkan pejalan kaki tunanetra pada jalur pedestrian terhadap kenyamanan dalam bermobilitas adalah ketersediaan area penyeberangan (zebra cross dan lampu lalu lintas), serta ketersediaan alarm peringatan (sound signal).

\subsection{Sintesis}

Sintesis mengenai persepsi dan preferensi terhadap jalur pedestrian dipertimbangkan berdasarkan aspek pengguna (tunanetra) dan aspek lingkungan, sehingga jalur pedestrian dapat berfungsi secara optimal dan aman serta nyaman dalam pemanfaatannya.

Rekomendasi disusun dengan menerapkan pedoman Teknis Fasilitas dan Aksesibilitas pada Bangunan Gedung dan Lingkungan, serta Pedoman Perencanaan, Penyediaan, dan Pemanfaatan Prasarana dan Sarana Jaringan Pejalan Kaki di Kawasan Perkotaan dalam penyelesaian masalah mengenai kondisi fisik jalur pedestrian saat ini. 
1. Jalur pedestrian

a. Lebar jalur pedestrian minimal $160 \mathrm{~cm}$. Perbedaan tinggi maksimal antara ruang pejalan kaki dan jalur kendaraan bermotor adalah $20 \mathrm{~cm}$, sementara perbedaan ketinggian dengan jalur hijau $15 \mathrm{~cm}$.

b. Jalur difabel diletakkan di sepanjang prasarana jaringan pejalan kaki. Pemasangan jalur pemandu perlu memperhatikan pola susunan ubin pemandu agar tidak terjadi disorientasi.

c. Permukaan jalan harus stabil, kuat, tahan cuaca, bertekstur halus tetapi tidak licin, serta tidak ada sambungan yang mengganggu aksesibilitas.

d. Jalur pedestrian harus bebas dari pohon, tiang, rambu, drainase dan benda yang menghalangi, serta tidak ada lubang dan jeruji yang membahayakan pejalan kaki.

e. Ram (ramp) diletakkan di setiap persimpangan, prasarana ruang pejalan kaki yang memasuki jalan masuk bangunan, dan pada titik-titik penyeberangan.

f. Lampu penerangan terletak setiap $10 \mathrm{~m}$. Tempat beristirahat atau duduk harus ada maksimal setiap $10 \mathrm{~m}$. Tempat sampah perlu tersedia sepanjang jalur pedestrian dengan jalur pemandu menuju street furniture.

g. Marka dan perambuan serta papan informasi (signage) diletakkan pada titik interaksi sosial (ruang tunggu terminal atau tempat pemberhentian bus atau di tepi persimpangan jalan) dengan besaran sesuai kebutuhan. Papan informasi berisi mengenai model kondisi jalur sirkulasi dan aksesibilitas dan kondisi sekitarnya. Model atau ilustrasi dari jalur pedestrian yang direkomendasikan bisa dilihat pada Gambar 3.

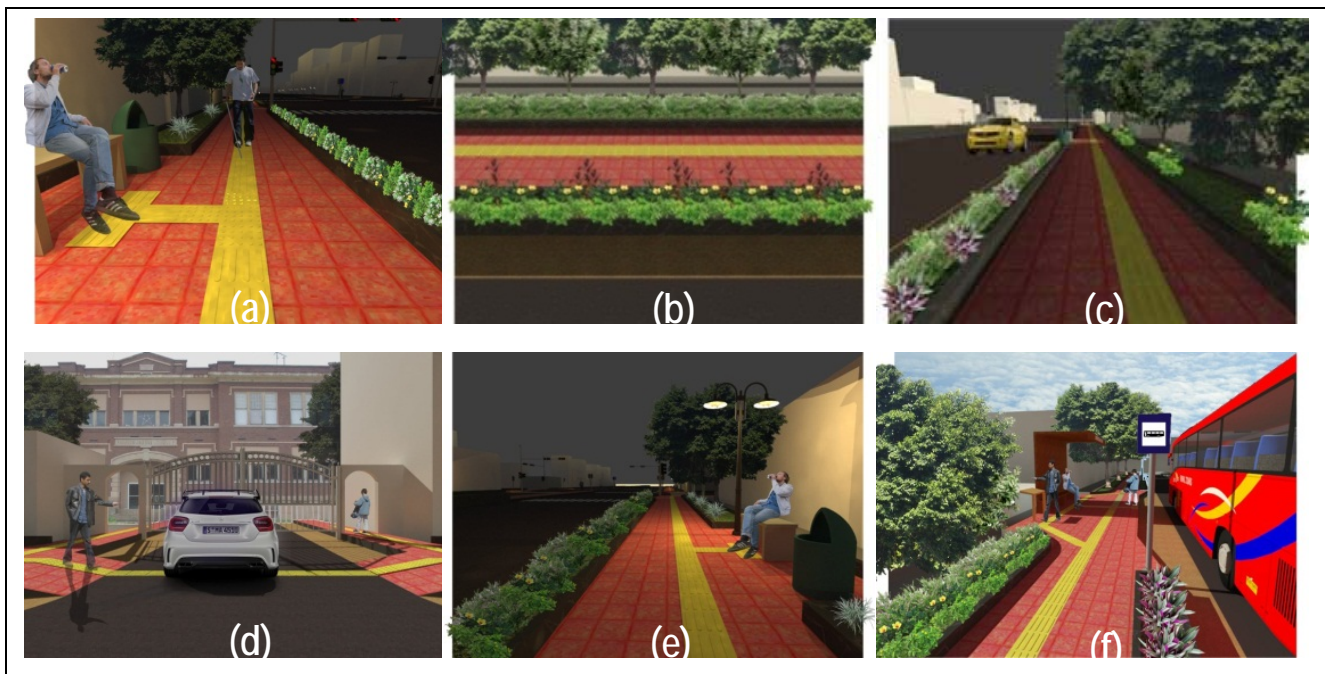

Gambar 3. Model Jalur Aksesibilitas

2. Area penyeberangan

Elevasi jalur pedestrian harus disesuaikan sehingga penyandang cacat mudah melalui tempat penyeberangan. Apabila jalan tersebut digunakan oleh orang tunanetra, berbagai perubahan dalam tekstur pedestrian dapat digunakan sebagai tanda-tanda praktis. Tempat penyeberangan orang ditandai dengan zebra cross. Apabila arus lalu lintas kendaraan dan arus pejalan kaki cukup tinggi, tempat penyeberangan orang dilengkapi dengan alat pemberi isyarat lalu lintas (traffic light). Ruang untuk area pemberhentian sementara harus diturunkan ketinggiannya dari median jalan, serta bebas hambatan. Pada lokasi dengan arus lalu lintas dua jalur, perlu disediakan median pada lokasi penyeberangan, sehingga penyeberang jalan cukup berkonsentrasi pada satu arah saja (Gambar 4). 


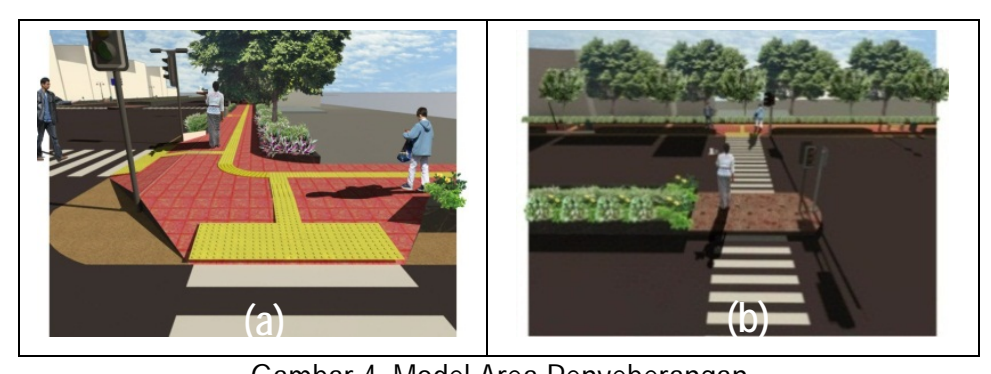

Gambar 4. Model Area Penyeberangan

3. Pemilihan tanaman tepi jalan

Tanaman tepi jalan pada jalur pedestrian yang ramah bagi pegguna penyandang tunanetra yang direkomendasikan pada jalur pedestrian Jalan P. B Sudirman Denpasar yaitu tanaman dengan karakter akar kuat ke dalam tanah, batang dan ranting kuat, tajuk tidak bercabang ke bawah, daun tidak mudah rontok dan tidak terlalu rimbun, bunga dan buah tidak mudah rontok, tanaman tidak menghasilkan getah beracun, tidak berduri, dan tidak menimbulkan alergi. Contoh beberapa jenis tanaman tersebut yaitu Filicium decipiens, Mimusops elengi, Gardenia jasminoides sebagai tanaman hias dan yang telah menjadi maskot Kota Denpasar serta memiliki aroma yang harum, dan tanaman lain sebagai variasi Jasminum sambac.

\section{Simpulan}

Berdasarkan hasil analisis data dan sintesis, disimpulkan bahwa inkonsisitensi ukuran dan elevasi pedestrian salah satu penyebab jalur pedestrian dinilai penulis tidak layak digunakan oleh penyandang tunanetra. Pengalaman dan kebiasaan dari mayoritas responden telah menghasilkan penilaian kondisi keamanan pada kategori cukup aman dengan persentase 40,4\%, dan cukup nyaman dengan nilai 54,9\%. Penilaian tersebut diberikan tanpa respon pemahaman dan pengetahuan tentang pedoman yang berlaku dan tanpa mempertimbangkan pejalan kaki yang tidak aktif menggunakan jalur pedestrian, sehingga penilaian tersebut hanya mewakili studi kasus dalam penelitian ini. Preferensi yang dibutuhkan pejalan kaki tunanetra terhadap kenyamanan dalam bermobilisasi adalah ketersediaan area penyeberangan serta ketersediaan alarm peringatan. Skenario ruang jalur pedestrian di sepanjang Jalan P. B Sudirman Denpasar yaitu menjadikan jalur pedestrian sebagai jalur mobilisasi yang mudah diakses oleh semua orang serta optimal dalam pemanfaatannya.

\section{Daftar Pustaka}

Badan Pusat Statistik Kota Denpasar. 2017. Denpasar dalam Angka 2016. Badan Pusat Statistik Kota Denpasar. Denpasar.

Dinas Pekerjaan Umum Kota Denpasar. 2016. Panjang dan Kondisi Trotoar di Kota Denpasar Akhir Tahun 2016. Dinas Pekerjaan Umum Kota Denpasar. Denpasar.

Dinas Perhubungan Kota Denpasar. 2015. Volume Lalu Lintas Kendaraan Tahun 2015. Dinas Perhubungan Kota Denpasar. Denpasar.

Indrawati, Aria. 2016. Tunanetra yang Menginspirasi. Wawancara oleh Kick Andy Metro TV dan ditayangkan 04 Maret, pukul 20.30 WIB (diakses melalui youtube pada tanggal 02 Juni 2016).

Pemerintah Daerah Kota Denpasar. 2015. Rencana Kerja Pembangunan Daerah KotaDenpasar Tahun 2015. Pemerintah Daerah Kota Denpasar. Denpasar.

Republik Indonesia. 2004. Undang-undang Republik Indonesia Nomor 38 Tahun 2004. Tentang Jalan. Departemen Dalam Negeri. Jakarta. 